\title{
Cesium Removal from Wastewater Using Banana Peel
}

\author{
Mohammed Nsaif Abbas*, Firas Saeed Abbas, Ishraq Khudhair Abass \\ Environmental Engineering Department, College of Engineering, Mustansiriyah University, Baghdad, Iraq
}

\begin{abstract}
Article Info
Volume 8, Issue 4

Page Number : 367-372

Publication Issue :

July-August-2021

\section{Article History}

Accepted : 02 Aug 2021

Published: 14 Aug 2021
\end{abstract}

\section{ABSTRACT}

The potential of banana peel (BP) on the cesium removal from aqueous solutions is study by using different design parameters by adsorption process. The design parameters studied to adsorb cesium using BP as an adsorbent material were initial concentration of cesium, absorbance material packing height which was $\mathrm{BP}, \mathrm{pH}$ of cesium feed inlet, treatment time, feed flow rate and feed temperature, results show that the higher removal efficiency was $97.50 \%$ for cesium from aquatic solution and this efficiency was decreased with increasing of initial concentration and flow rate while the removal efficiency increased with increasing $\mathrm{pH}$, sorption media bed height and feeding temperature. By this way we can possess different benefits which are: remove the hazard and toxic cesium contaminated the water and get rid of waste BP.

Keywords : Banana Peel, Cesium, Aqueous Solutions, Adsorption, Residue, Wastewater.

\section{INTRODUCTION}

Cesium is one of alkaline and radioactive element subsists in the nature fundamentally by erosion and from rocks and minerals, Ghaffar et al. (2012). The Dutch scientist, Bunsen and Kirchhoff, disclosed cesium in 1860 using the newly sophisticated flame spectroscopy process. Because of its bright blue emission spectrum, they selected a name originated from the Latin word caesius, meaning sky-blue, Coplen and Peiser (1998). Cesium is a rare element comparatively; it is predestined to about approximately $3 \mathrm{ppm}$ in the Earth's crust. Cesium is existed in the liquid phase and crystallizes last. Therefore, the largest sediment of cesium is zone pegmatite ore resources formed by fructify process, Turekian and Wedepohl (1961). Cesium salts are used to fortified many glass types. Cesium nitrate is used to manufacture optical glasses. Sometimes it is used to eliminate traces of oxygen from the vacuum tubes and from light bulbs. In photoelectric cells, in increasing the sensitivity of electron tubes and in optical instruments Cesium is used in chloride form. Cesium is used also in atomic clocks and lastly in ion propulsion process. It is used as a catalyst promoter for many reactions in industry; consolidating the function of other metal oxides in the capacity and for the hydrogenation of organic compounds. It is sent out to the air, water and soil by effluents of industries, treating ores. Due to these activities, different wastes containing various radioactive isotopes and ions of cesium were created pollution of the water resources like rivers, lakes or ground water, Sasaki (2013). Cesium is postulated probably risk to the environment and to human health, because wide cesium compounds are very soluble in water. The 
high solubility of cesium results in its transfer from surface water to groundwater. Because it's yield in nuclear power plants in high rates, having long halflives (half-life of ${ }^{135} \mathrm{Cs}$ is $2.3 \times 10^{6}$ years, ${ }^{137} \mathrm{Cs}$ is 30 years and ${ }^{134} \mathrm{Cs}$ is 2 years) and its high solubility in aqueous solutions, all these reasons cause its dangerous effects, Cortés-Martínez (2010). When human exposure to cesium through breathing, drinking or eating digest, diarrhoea, nausea, hyperirritability, vomiting, spasms and bleeding may be result and if exposure continues for a long time people may be lose consciousness. Finally coma or even death may carry out, ATSDR (2004). Adsorption processes is one of the most commonly and efficacious methods in radioactive wastewaters treatment. Recently, banana peel which is a type of agriculture waste is used as adsorbent media for adsorption process of many pollutants because it is available, very inexpensive and ability to remove different heavy metals by this process, thus the banana peel usage will decrease the cost of wastewater treatment considerably and would represent practical benefit of agriculture waste residue in disposal toxic matter in save way, Kim (2013). The aim of this investigation is studying the ability of banana peel (low coast adsorbent material) for removing cesium from simulated synthetic aqueous solution, and utilization from the banana peel residue in eco-friendly method.

\section{METHODS AND MATERIAL}

\section{Banana peel (adsorbent media)}

Banana peel (BP), mature banana with yellow peel, was collected from local market in Baghdad. The BP was washed three times with excess double distilled water and boiled to remove dust, impurities and other fine dirt particles that may be attached to the BP. The washed BP was cut into small pieces $(0.5-1 \mathrm{~cm})$ after that and then dried at $50^{\circ} \mathrm{C}$ for 24 hours. The surface area of BP was measured by BET method (Brunauer Emmett - Teller nitrogen adsorption technique) and was found about $13.5 \mathrm{~m} 2 / \mathrm{g}$. X-ray diffraction (XRD) of $\mathrm{BP}$ were presented in Figure 1.

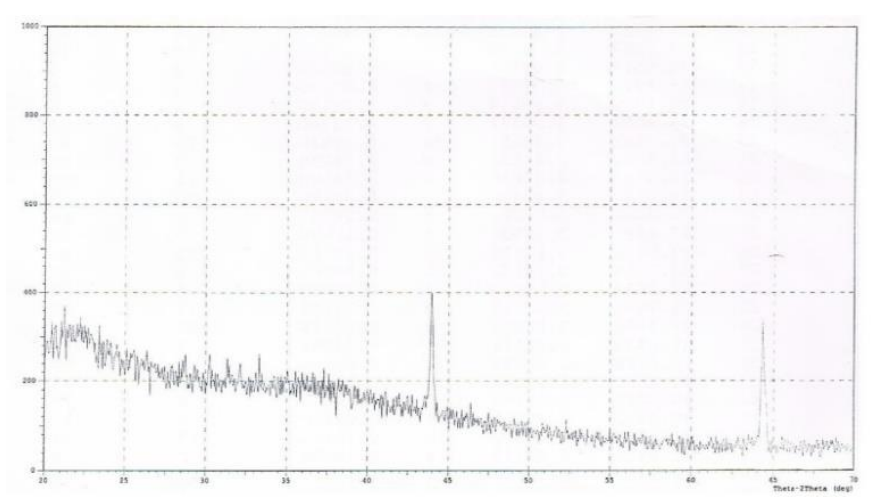

Figure 1: XRD of Banana Peel

\section{Stock solutions}

In order to avoid interference with other elements in wastewater, the experiments in this study were carried out using simulated synthetic aqueous solution (SSAS) of different cesium concentrations. $1000 \mathrm{mg} / \mathrm{l}$ stock solution of cesium was prepared by dissolving known weight of cesium nitrate $\mathrm{CsNO}_{3}$ in one litre of double distilled water, all solutions using in the experiments were prepared by diluting the stock solution with double distilled water to the desired concentrations for the experimental work of this investigation. The cesium concentrations were measured using spectrophotometer method using spectrophotometer thermo - genesys $10 \mathrm{UV}$, USA.

\section{Sorption unit}

Fixed bed column of continuous mode experiments were conducted in order to examine cesium removal by treated SSAS of above cesium at desired concentration with the various bed heights of the BP (adsorbent media) using different flow rates of SSAS of cesium at various $\mathrm{pH}$. The $\mathrm{pH}$ value was adjusted using $0.1 \mathrm{~N} \mathrm{NaOH}$ and $0.1 \mathrm{~N} \mathrm{HCl}$ solutions. The sorption unit consists of two glass container for SSAS of cesium one for inlet feed and another for outlet each of (1 liter) capacity. Glass column has $2.54 \mathrm{~cm}$ ID and $150 \mathrm{~cm}$ height. The sorption column packed with adsorbent media to a height of $(10,20,30,40,50,60$, $70,80,90$ and $100 \mathrm{~cm}$ ) supported from the top and the bottom by glass hollow cylinder layer, each cylinder have $(0.5 \mathrm{~cm}$ ID, $0.1 \mathrm{~cm}$ thickness and $1 \mathrm{~cm}$ 
long). Before starting the runs, the packed bed sorption column was rinsed by double distilled water down flow through the column. The adsorbent media is packed in the column to the desired depth, and fed to it as slurry by mixing BP with distilled water in order to avoid the formation of air bubbles inside the media. After the packed bed sorption column was accommodation and putting the required amount of adsorbent media, the adsorption process started by allowing the cesium SSAS of required concentration and $\mathrm{pH}$ down flow through the sorption column from inlet container by gravity at a precise flow rate in experiment which is adjusted by rotameter. To determination the best operational conditions, the experiments were carried out at a temperature between $\left(20-55^{\circ} \mathrm{C}\right)$, various $\mathrm{pH}$ values which are (1-8) and initial feed concentrations of SSAS of different cesium which are between (1-100) mg/l each one alone and at different flow rates which are between (5-100) $\mathrm{ml} / \mathrm{min}$ for SSAS of cesium initial feed concentration. Outlet samples after treatment in each experiment were collected every 10 minutes from the bottom of packed column and the unabsorbed concentration of cesium in SSAS was analyzed by spectrophotometer.

\section{Result and Discussion}

The ability of BP to remove cesium from SSAS in fixed bed column of continuous mode at various parameters which are pH's of SSAS of cesium $(p H)$, height bed of adsorbent media BP $(h)$, flow rates of SSAS $(F)$, SSAS temperature $\left(T_{\text {feed }}\right)$ and time of treatment $(t)$ was investigated. The experiments were achieved by varying all above parameters for different initial concentrations $\left(C_{0}\right)$ of SSAS of cesium. Thus, the results obtained are explained below.

\section{Effect of Initial Concentration}

The results showed that using adsorbent material, the percent removal of cesium was decreased when the initial concentration $\left(C_{0}\right)$ of SSAS of cesium was increased at constant other variables as shown in Figure 2. This can be explained by the fact that the initial concentration of cesium had a restricted effect on cesium removal capacity; simultaneously the adsorbent media had a limited number of active sites, which would have become saturated at a certain concentration. This was lead to the increase in the number of cesium molecules competing for the available functions groups on the surface of adsorbent material. Since the solution of lower concentration has a small amount of cesium than the solution of higher concentration of it, so the percent removal was decreased with increasing initial concentration of cesium. For adsorbent media, higher percent removal were $97.50 \%$ for cesium at initial cesium concentration of $1 \mathrm{mg} / \mathrm{l}$, so adsorbent material was found to be efficient to cesium removal from SSAS and wastewater.

\section{Effect of $p H$}

The results showed that using adsorbent material BP, the percent removal of cesium was increased when the $\mathrm{pH}$ of SSAS of cesium increased too, at constant other variables as shown in Figure 3. This increase can be explained as follows: the $\mathrm{pH}$ of the solution affects the surface charge of the adsorbent, degree of ionization along with speciation of different pollutants. The effect $\mathrm{pH}$ was very less pronounced in adsorption but had a marked effect on the stability of cesium. At low $\mathrm{pH}$ values cesium exists as cesium hydroxide which is a weak soluble in water. This affinity of water at low $\mathrm{pH}$ prevents its adsorption onto BP. Also at a higher $\mathrm{pH}$ the deprotonation on BP surface provides functional groups, for chemisorption, on its surface that can undergo ion exchange type of interaction with cesium. In the alkaline conditions free cesium is present predominantly in cesium hydroxide form. Equilibrium adsorption between BP and cesium indicates that extent of adsorption is not dependant on $\mathrm{pH}$ in high $\mathrm{pH}$ ranges, Abolghasemi et al. (2008). 


\section{Effect of Adsorbent Media Bed Height}

The results elucidated that when the adsorbent media bed height was increased, the percent removal of cesium was increased too at constant other variables as shown in Figure 4. The increased of bed height $(h)$ meaning increased in the amount of adsorbent media $\mathrm{BP}$, thus increasing the surface area of adsorbent material, hence increased the number of active sites in the adsorbent material surface i.e. increased the availability of binding sites for adsorption and consequently increase cesium removal capacity on BP. This lead to increase the ability of adsorbent media to adsorb greater amount of cesium from SSAS at different initial concentrations and ultimately the percent removal of cesium increased.

\section{Effect of Flow Rate}

The results illustrated that when the flow rate of SSAS of cesium was increased, the percent removal of cesium was decreased at constant other variables as shown in Figure 5. This may be due to the fact that when the flow of SSAS of cesium increasing, the velocity of SSAS in the column packed with the adsorbent media BP was increasing too, so the solution spend shorter time than that spend in the column while at low flow rate, and the SSAS of cesium resides in the column for a longer time, therefore undergoes more treatment with the adsorbent media, thus the adsorbent media uptake low amount of cesium from SSAS of cesium for high flow rate, therefore the percent removal of cesium was decreased when the flow rate was increased.

\section{Effect of Feed Temperature}

The results demonstrated that when the temperature of feed which was SSAS of cesium was increased, the percent removal of cesium was increased too at constant other variables as shown in Figure 6. The effect of temperature is fairly common and increasing the mobility of the acidic ion. Furthermore, increasing temperatures may produce a swelling effect within the internal structure of the adsorbent media enabling cesium ions $\left(\mathrm{Cs}^{+}\right)$to penetrate further. It was indicated that cesium adsorption capacity increased with increasing feed temperature from 5 to $55^{\circ} \mathrm{C}$. This effect may be due to the fact that at higher temperature an increase in active sites occurs due to bond rupture.

\section{Effect of Treatment Time}

The results demonstrated that when the treatment time of SSAS of cesium increased the percent removal of cesium increased at constant other variables as shown in Figure 7. This may be due to the fact that when the treatment time of cesium SSAS increasing and the velocity of SSAS in the column packed with the adsorbent material was remaining constant, the solution spend longer time than that spend it when the time of treatment decreased, so the adsorbent material uptake more amount of cesium from SSAS, therefore the percent removal of cesium from SSAS was increased.

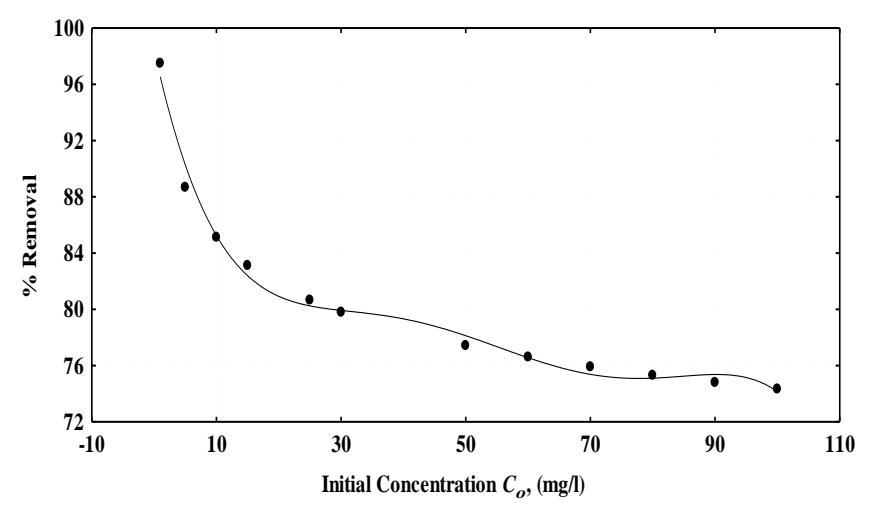

Figure 2: Effect of initial concentration $\left(C_{\mathrm{o}}\right)$ on the percent removal of cesium @ $T_{f}=55^{\circ} \mathrm{C}, h_{b}=1 \mathrm{~m}, p H=8$, $t=60 \mathrm{~min}$. and $F=5 \mathrm{ml} / \mathrm{min}$. 


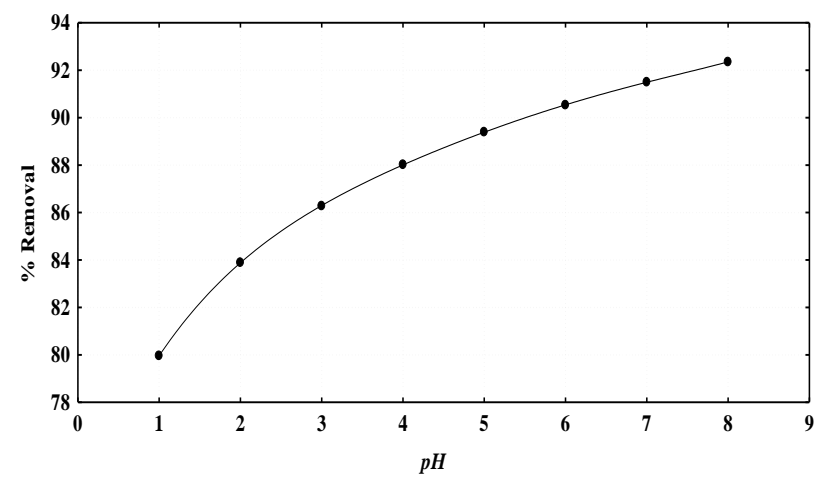

Figure 3: Effect of $\mathrm{pH}$ on the percent removal of cesium @ $\mathrm{C}_{\circ}=1 \mathrm{mg} / \mathrm{l}, \mathrm{Tf}=55^{\circ} \mathrm{C}, \mathrm{hb}=1 \mathrm{~m}, \mathrm{t}=60 \mathrm{~min}$. and $\mathrm{F}=5 \mathrm{ml} / \mathrm{min}$.

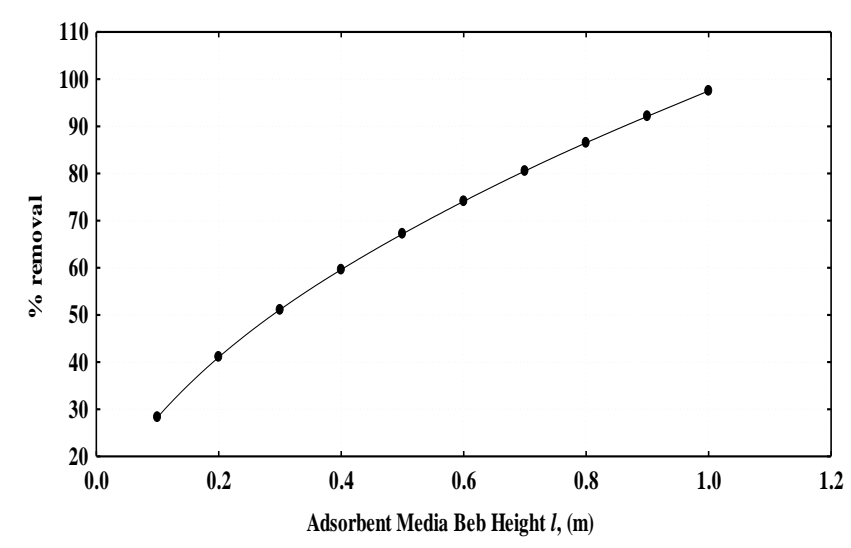

Figure 4: Effect of adsorbent media bed height $(\mathrm{hb})$ on the percent removal of cesium @ $\mathrm{C}_{\circ}=1 \mathrm{mg} / \mathrm{l}, \mathrm{pH}=8$, Tf $=55^{\circ} \mathrm{C}, \mathrm{t}=60 \mathrm{~min}$. and $\mathrm{F}=5 \mathrm{ml} / \mathrm{min}$

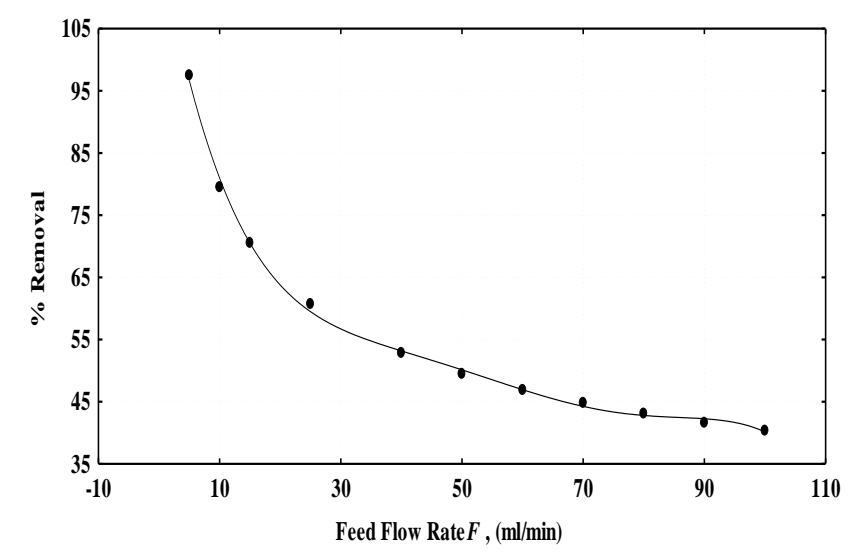

Figure 5: Effect of SSAS flow rate $(\mathrm{F})$ on the percent removal of cesium @ $\mathrm{C}_{\circ}=1 \mathrm{mg} / \mathrm{l}, \mathrm{pH}=8, \mathrm{Tf}=55^{\circ} \mathrm{C}, \mathrm{hb}$ $=1 \mathrm{~m}$ and $\mathrm{t}=60 \mathrm{~min}$.

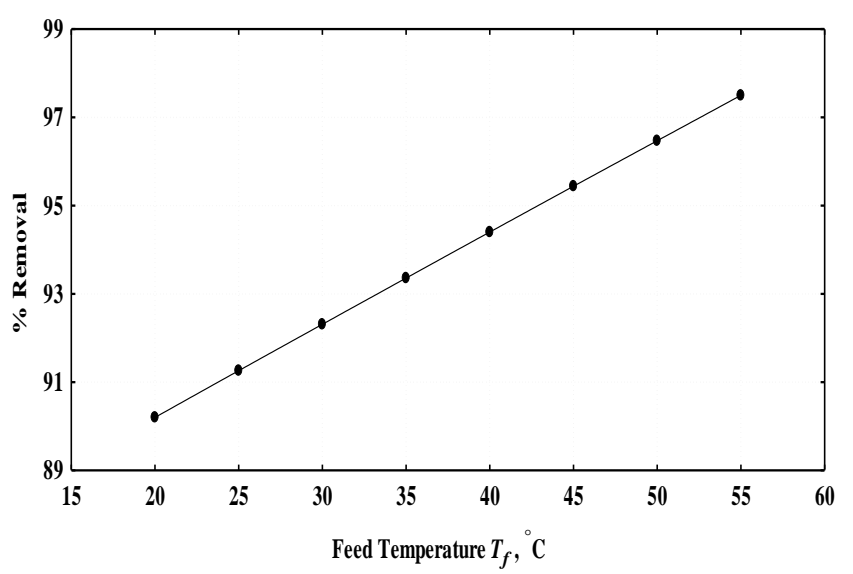

Figure 6: Effect of feed temperature (Tf) on the percent removal of cesium @ $\mathrm{C}_{0}=1 \mathrm{mg} / \mathrm{l}, \mathrm{pH}=8, \mathrm{hb}=$ $1 \mathrm{~m}, \mathrm{t}=60 \mathrm{~min}$. and $\mathrm{F}=5 \mathrm{ml} / \mathrm{min}$.

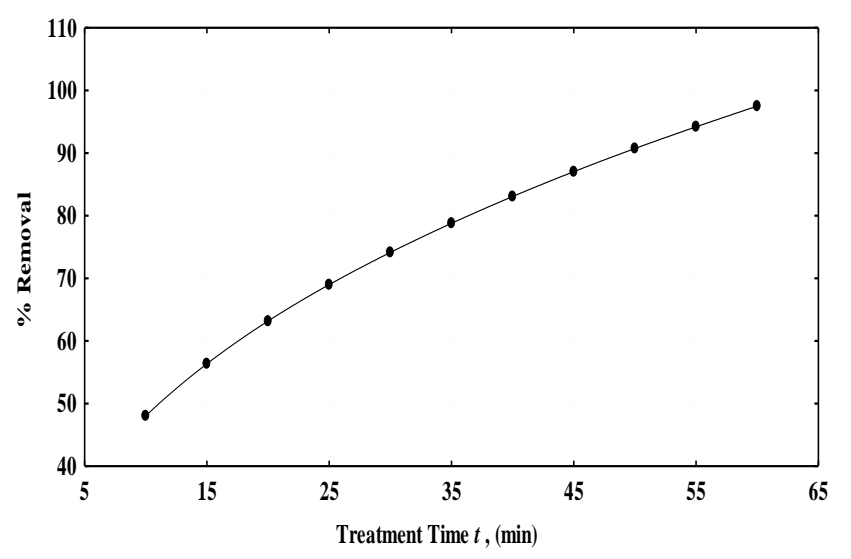

Figure 7: Effect of treatment time $(\mathrm{t})$ on the percent removal of cesium @ $\mathrm{C}_{\circ}=1 \mathrm{mg} / \mathrm{l}, \mathrm{Tf}=55^{\circ} \mathrm{C}, \mathrm{pH}=8, \mathrm{hb}$ $=1 \mathrm{~m}$, and $\mathrm{F}=5 \mathrm{ml} / \mathrm{min}$.

\section{IV.CONCLUSION}

The following conclusions can be drawn:

1. BP showed a good ability to remove cesium from SSAS using fixed bed adsorption unit. So, it could be recommended for removal of cesium from wastewater instead of other material because it is valid, cheaper, economical, easy and simplicity for using, and has a high ability to adsorb cesium, can be used several times by costly regeneration method and can be used finally in another benefit use. 
2. Maximum removal of cesium was $97.50 \%$ at initial cesium concentration of $1 \mathrm{mg} / \mathrm{l}$.

3. The percentage removal of cesium was increased with decreasing flow rate of SSAS, and initial concentration of cesium while the percentage removal was increasing with increasing of $\mathrm{pH}$, treatment time and the height of adsorbent material RH.

\section{REFERENCES}

[1]. Abolghasemi, H., Rostamnejhad, M., Momenzade, S., Hadadi, N., 2008. Application of Natural Vermiculite for Cesium Removal from Radioactive Aqueous Waste. J. of Nuclear Sci. and Tech No. 44, pp. 35-39.

[2]. Agency for Toxic Substances and Disease Registry (ATSDR). 2004. Toxicological profile for Cesium. Atlanta, GA: U.S. Department of Health and Human Services, Public Health Service, http://www.atsdr.cdc.gov/toxprofiles/tp157.pdf.

[3]. Blanchard, G., Charcosset, H., Chenebaux, M. T., Primet, M., 1979. Preparation of Alumina or Silica Supported Platinum-Ruthenium Bimetallic Catalysts. Preparation of Catalysts II (Delmon, B., Grange, P., Jacobs, P. and Poncelet, G.), p. 197, Elsevier, Amsterdam.

[4]. Cesar L., 1999. Simulation of Liquid Chromatography and Simulated Moving Bed (SMB) Systems. MSc. Thesis, Hamburg Tchnische University .

[5]. Cortés-Martínez, R., Olguín, M.T., Solache-Ríos, M., 2010. Cesium sorption by clinoptilolite-rich tuffs in batch and fixed-bed systems. Desalination, 258:164-170.

[6]. Coplen, T. B., Peiser, H. S., 1998. History of the recommended atomic-weight values from 1882 to 1997: a comparison of differences from current values to the estimated uncertainties of earlier values. Pure Applied Chemistry. 70 (1): 237-257.

[7]. Ghaffar, A., Mazhar, F., Mashiatullah, A., Alaamer A. S., 2012. A Modified Method for
Removal and Stabilization of Cesium Metal in the Vitrified Matrix. Journal of Water Chemistry and Technology, Vol. 34, No. 6, pp. 258-263.

[8]. Kim C. K., Kong, J. Y., Chun, B. S., Park, J. W., 2013. Radioactive removal by adsorption on Yesan clay and zeolite, Environ Earth Sci, 68:2393-2398.

[9]. Mohammed, M. M., Zidan F.I., Thabet M., 2008. Synthesis of ZSM-5 Zeolite from Rice Husk Ash: Characterization and Implication for Photocatalytic Degradation Catalyst. Micropores and Mesoporous Materials Journal, 108 193-203.

[10].Rahman, M. M., Hasnida, N., Wan Nik, W.B., 2009. Preparation of Zeolite Y Using Local Raw Material Rice Husk As a Silica Source. J. Sci. Res. 1 (2), 285-291.

[11].Sasaki, T., Okabe, J., Henmi M., Hayashi, H., Iida, Y., 2013. Cesium (Cs) and strontium (Sr) removal as model materials in radioactive water by advanced reverse osmosis membrane. Desalination and Water Treatment, 51 16721677.

[12].Sherman, J.D., Danner, R.P., Dranoff, J.S., Sweed, N.H., 1978. Adsorption and Ion Exchange Separation, AIChE, 74, 179.

[13].Turekian, K.K.; Wedepohl, K. H., 1961. Distribution of the elements in some major units of the Earth's crust, Geological Society of America Bulletin. 72 (2): 175-192.

\section{Cite this article as :}

Mohammed Nsaif Abbas, Firas Saeed Abbas, Ishraq Khudhair Abass, "Cesium Removal from Wastewater Using Banana Peel", International Journal of Scientific Research in Science, Engineering and Technology (IJSRSET), Online ISSN : 2394-4099, Print ISSN : 2395-1990, Volume 8 Issue 4, pp. 367-372, JulyAugust 2021. Available at doi : https://doi.org/10.32628/IJSRSET218458 Journal URL : https://ijsrset.com/IJSRSET218458 